Article

\title{
Analysis of the Satisfaction Degree of Students at Spain's Physiotherapy Universities in Relation to Online Teaching during the COVID-19 Pandemic
}

\author{
Isabel Escobio-Prieto ${ }^{1, *(\mathbb{C})}$, Raquel Sobrino-Sánchez ${ }^{2}$, José Antonio Mingorance ${ }^{3}{ }^{(0)}$, Manuel García-Marín ${ }^{4}(\mathbb{D}$, \\ Antonio Matas-Terrón ${ }^{5}\left[\right.$ and Manuel Albornoz-Cabello ${ }^{1}[$ \\ 1 Department of Physiotherapy, Faculty of Nursing, Physiotherapy and Podiatry, University of Sevilla, \\ 41009 Sevilla, Spain; malbornoz@us.es \\ 2 Department of Physiotherapy, University School of Osuna, 41640 Sevilla, Spain; raquelss@euosuna.org \\ 3 Department of Nursing and Physiotherapy, University of the Balearic Islands, 07122 Palma, Spain; \\ josea.mingorance@uib.es \\ 4 Health Sciences Department, University of Jaen, 23071 Jaen, Spain; mgm00049@red.ujaen.es \\ 5 Department of Theory and History of Education and Methods of Research and Diagnosis in Education, \\ University of Malaga, 29071 Malaga, Spain; amatas@uma.es \\ * Correspondence: iescobio@us.es
}

check for updates

Citation: Escobio-Prieto, I.; Sobrino-Sánchez, R.; Mingorance, J.A.; García-Marín, M.; Matas-Terrón, A.; Albornoz-Cabello, M. Analysis of the Satisfaction Degree of Students at Spain's Physiotherapy Universities in Relation to Online Teaching during the COVID-19 Pandemic. Sustainability 2021, 13, 13628. https:/ / doi.org/10.3390/su132413628

Academic Editors: Tomasz Rokicki, Sebastian Saniuk and Dariusz Milewski

Received: 14 November 2021 Accepted: 5 December 2021 Published: 9 December 2021

Publisher's Note: MDPI stays neutral with regard to jurisdictional claims in published maps and institutional affiliations.

Copyright: (c) 2021 by the authors. Licensee MDPI, Basel, Switzerland. This article is an open access article distributed under the terms and conditions of the Creative Commons Attribution (CC BY) license (https:/ / creativecommons.org/licenses/by/ $4.0 /)$.

\begin{abstract}
Student satisfaction is a crucial aspect in the quality assessment of higher education. The aim of the present study was to assess the degree of satisfaction among students in the Faculties of physiotherapy throughout Spain concerning online teaching during the State of Emergency due to the COVID-19 pandemic. This was a quantitative study with a cross-sectional observational design. The online questionnaire DISFISCOVID was distributed to 24 physiotherapy faculties across Spain. A sample of 348 physiotherapy students from 14 Spanish universities completed the questionnaire. It showed high reliability evidence, achieving Cronbach's alpha indices higher than 0.870 , alongside a McDonald's $\omega \mathrm{H}$ of 0.876 . On the whole, students were not satisfied with online learning during the State of Emergency, considering it unsuitable for their learning in either the theoretical or practical field of subjects in the degree of physiotherapy. In conclusion, the perception of physiotherapy students concerning the teaching they received, as far as practical contents and assessment methods are concerned, was not very satisfactory in those Faculties in which online learning platforms were not being used beforehand, and was more satisfactory when teaching was carried out in-person in the classroom.
\end{abstract}

Keywords: survey; physical therapist student; university; COVID-19 pandemic; E-learning; online classes

\section{Introduction}

The new coronavirus infection (COVID-19), caused by a novel virus SARS-CoV-2, is now a pandemic announced by the World Health Organization, raising concerns of widespread panic and increasing anxiety in individuals [1]. The pandemic has affected the education system across the world [2-4]. In response to the COVID-19 outbreak, the Spanish government, like all other countries worldwide, ordered the cessation of inperson teaching at all levels, including all state Universities. This emergency measure was necessary in order to prevent the spread of infection and to ensure social distancing. A State of Emergency (SE) was declared through Royal Decree 463/March 2020 [5].

With the generalised implementation of social distancing and self-isolation policies, it was not feasible for either teaching staff or students to attend classes or exams as they had been doing before the SE [6]. Hence, the progress of academic year 2019-2020 was unexpectedly altered, giving rise to one-of-a-kind challenges throughout the university world $[2,4,7]$. The cancellation of all in-person classes forced urgent measures to be taken 
in the curricula of health sciences (HS) at universities, such as preadaptation of teaching methods by introducing distance learning $[3,4,7,8]$. Thereby, the use of virtual platforms, which students were becoming familiar with but which many were still opposed to using, took on special importance [9].

The distance learning education model originated at the university of Tubinga (Germany) in the 1960s. This training modality evolved into an educational process that people had access to from different places and at different times [10], giving rise through a series of information and communication technologies (ITC) including Internet, Moodle, and digital platforms to virtual learning environments such as E-learning [10-12]. E-learning has been defined as an educational method that facilitates learning by the application of information and communication technology, providing an opportunity for learners to have access to all the required education programmes both in-person and from a distance [9-11].

Distance learning offers students control over the contents, pace and sequence of learning, the time and even the means, enabling them to adapt to their personal circumstances and situation [13]. While was being used at universities as a blended learning method [4,11], its use was accelerated during the COVID-19 pandemic with changes being imposed overnight, becoming exclusively online learning [4].

University education is living an unprecedented time [14], which could lead to success providing common sense prevails along with generosity towards all the parties involved (lecturers, students, and service staff) in this teaching-learning process [15].

In Spain, there are a total of 50 public universities, in which there are 235 in-person campuses and 113 distance learning offices. In the private sector we have 34 universities, five of which offer online teaching [16], and none of which provide distance or blended undergraduate training in physiotherapy. The search for quality and excellence in education in physiotherapy requires future professionals to acquire learning in real clinical environments, involving interaction with their lecturers, peers, and above all patients, in order to achieve the process of intellectual, emotional, and human maturing that this profession requires [10]. ICT helps to attain these goals, but cannot replace in-person experience in real settings [10].

At the educational level, this impact will not be known for quite a long time; therefore, we believe it is important to record and study the full reach of the changes in teaching in this branch of healthcare implemented in response to this global emergency, in order to clarify how the current academic year has progressed and what line should be followed [17]. Hence, it is necessary to study standards for the purpose of ensuring that this online teaching is suited to preparing our students when it comes to working with patients $[7,17]$.

Further, these physiotherapy students have received purely online classes for a prolonged period of time, a situation never before witnessed. To the best of our knowledge, this study is the first of its kind in analyzing satisfaction with e-learning methods in physiotherapy education during this pandemic in Spain. That is, it is unknown whether students are aware of the magnitude and importance of this educational change in their studies. In addition, it is unknown how these months of confinement and e-learning affected the different academic years. Thus, the main objective of the present study is to assess student satisfaction with online teaching during the sudden SE due to COVID-19 in Spanish physiotherapy Universities.

\section{Materials and Methods}

This study had a multicenter cross-sectional, self-administered, anonymous, survey design in 14 physiotherapy faculties in Spain, conducted in June 2020 after classes were over. To design the study in order to analyze the internal data structure, an Exploratory Factorial Analysis (EFA) was conducted, and the reliability of the subscales was checked using McDonald's omega coefficient. 


\subsection{Study Population}

The sample consisted of undergraduate physiotherapy students at 14 faculties of Spain. A total of 348 students aged over 18 years were recruited in June 2020. All enrolled participants were informed of the purpose and procedures of the study. The only criterion for inclusion was to be studying physiotherapy during the SE.

\subsection{Instrument}

The DISFISCOVID questionnaire was sent to ten subject experts for face validation. In addition, a pilot test was conducted among 80 students to define its content and comprehension. Items were classified into the following domains: (1) Theoretical teaching (eight items), (2) Practical teaching (ten items), and (3) Assessment (four items). Respondents were asked about their time during the SE. Twelve additional items were also implemented to collect data related to sociodemographic and descriptive characteristics. A Likert scale ranging from 1 to 5 was used for all items according to the degree of agreement with the statements they contained: the higher the score, the greater the degree of agreement, with the value six representing the 'don't know/no answer'.

The questionnaire showed evidence of high reliability, achieving Cronbach's alpha indices greater than 0.870 and McDonald's $\omega \mathrm{H}$ of 0.876 . The analysis showed a general Kaiser-Meyer-Olkin (KMO) value of 0.893 , together with a significance of Bartlett's test of sphericity (Chi-square $=1980 ;$ g.l. $=231 ; p<0.001)$. The number of factors extracted was five, with $60.3 \%$ variance explained by these factors.

The free online survey tool "Google forms" (https:/ / www.google.com/forms/about/) was used to disseminate, collect and export the data of the questionnaire. An explanation of the study purpose, a description of the questionnaire (including the number of items and the expected duration of its completion), information about the research team involved in the project as well as the link for access to the questionnaire were included in the cover letter attached to the request for collaboration sent to the physiotherapy departments of the Universities of physiotherapy in Spain. The questionnaire was an open survey, and therefore not password-protected. Prior to sending out the link, the usability and technical functionality of the link and the questionnaire was tested.

Once the participant had access to it, the presentation screen included information about the purpose of the study and how the online platform worked, as well as information on data handling, anonymity, informed consent, approval by the Ethics Committee, agreement with the Declaration of Helsinki, and contact with the principal investigator of the project.

We stored and limited multiple entries with the same IP address because we did not want to permit the same student to respond with multiple questionnaires.

Then, the participants voluntarily completed the corresponding electronic questionnaire, implemented through the online survey creation tool "Google Forms".

The questionnaire consisted of two pages (screens), with 35 items per screen. Participants were able to review or change responses using a back button. Students were encouraged to help spread the questionnaire link among their contacts.

\subsection{Statistical Analysis}

Initially, the data were split into two datasets at random. The first $(70 \%$ of the total) was the training dataset, and the other was the used as testing data. In order to analyze the internal data structure, an Exploratory Factorial Analysis (EFA) was conducted with the test dataset after it was confirmed that the sample had enough size (more than 150 cases, and at least five cases for each variable), as proposed by Pallant (2010). Specifically, principal component axis factoring with varimax rotation was conducted to examine whether subscales emerged and to analyze item coherence, in accordance with the advice of Carretero-Dios and Pérez [18]. The number of factors was determined based on eigenvalue greater than 1 along with a scree plot. On the other hand, a conservative criterion was 
also used, considering loads below 0.40 as low $[19,20]$. In addition, the reliability of the subscales was checked using McDonald's omega coefficient.

A confirmatory factorial analysis was conducted based on the previous exploratory analysis result, over 30\% of original dataset. A Confirmatory Factor Analysis (CFA) provides a more powerful method than EFA to determine the best-fitting factor structure of the scale because individual items are a priori predicted to load only on their theoreticallydriven latent variables, rather than loading on all latent variables as in the exploratory factor analysis [21]. A Maximum Likelihood Estimation (MLM) was also conducted, as it has been shown to perform well even under non-normal conditions [22].

The following goodness-of-fit indexes were developed: (a) Comparative Fit Index (CFI), obtained from a free distribution estimation due to the ordinal scale of the observed variables (values greater than 0.95 indicate a good fit of the model [23]); (b) Root Mean Square Error of Approximation (RMSEA; values smaller than 0.05 indicate a good fit of the model and values up to 0.08 represented a reasonable error of approximation to the population [24]); and (c) Standardized Root Mean-Square (SRMR; values between 0 and 0.5 involve high fix, and values from to 0.5 to 1 indicate acceptable fix [24]). On the other hand, another CFA was conducted to analyze the feasibility of the theoretical three-dimensional model proposed initially. The fit measures between both models were compared.

After defining the model, all scores on the subscales were calculated by averaging their items and a descriptive analysis was conducted, including differences analysis between gender, course, and university. The convergence and divergence validity were not calculated because no previous comparable validated instrument was found.

$R$ version 3.6.1 [25] and SPSS version 24 were used for all analyses.

\subsection{Ethical Considerations}

The study protocol was supervised by the institutional ethics committee CEI University Hospital Virgen Macarena and Virgen del Rocio, with ethics approval number 1892-N-20. The research was conducted according to the Declaration of Helsinki. All enrolled participants were informed of the purpose of the study and their participation was voluntary. No incentives were provided for participation.

\section{Results}

An initial analysis of all the data in the sample showed that 148 were male while 200 were female. By age, $57.50 \%$ were between 21 and 30 years old, followed by the group of 18 - to 20 -year-olds (36.20\%); 36\% men and 36\% women were between 18 and 20 years of age. However, $62 \%$ women were between 21 and 30 years of age, as opposed to $51 \%$ men. In the same line, only $2 \%$ women were over 30 years old, compared to $5 \%$ men.

With regard to the university of origin, the frequencies are presented in Table 1, together with the percentage in the training group and the percentage in the verification group.

Table 1. Frequency and percentage of participants by University of origin.

\begin{tabular}{cccccccccc}
\hline Group & Sevilla & Cádiz & Córdoba & Baleares & Jaén & León & Osuna & Other & Total \\
\hline Training & 53 & 7 & 4 & 13 & 20 & 2 & 1 & 5 & 105 \\
& $50.48 \%$ & $6.67 \%$ & $3.81 \%$ & $12.38 \%$ & $19.05 \%$ & $1.90 \%$ & $0.95 \%$ & $4.76 \%$ & \\
Check & 98 & 13 & 17 & 22 & 45 & 13 & 20 & 14 & 242 \\
& $40.50 \%$ & $5.37 \%$ & $7.02 \%$ & $9.09 \%$ & $18.60 \%$ & $5.37 \%$ & $8.26 \%$ & $5.79 \%$ & \\
Total & 151 & 20 & 21 & 35 & 65 & 15 & 21 & 19 & 347 \\
\hline
\end{tabular}

Note: Chi-cuadrado $=12.60 ;$ g.l. $=7, p=0.083$.

In none of the above cases were any statistically significant differences found between the training data and the verification data.

Principal Component Analysis (PCA) was applied to the training data set. The analysis showed a general KMO value of 0.893 , together with the significance of Bartlett's sphericity test $($ Chi-square $=1980 ;$ g.l. $=231 ; p<0.001)$. The number of factors extracted was five, 
with $60.30 \%$ variability explained by these factors. In relation to the uniqueness or specific variance attributed to each variable, the items present values that lie between 0.196 (Item 18) and 0.703 (Item 5). Table 2 presents the principal component loadings for each item.

Table 2. Components loadings for each item.

\begin{tabular}{|c|c|c|c|c|c|c|}
\hline & 1 & 2 & 3 & 4 & 5 & Unicidad \\
\hline Item 18 & 0.826 & & & & & 0.196 \\
\hline Item 13 & 0.781 & & & & & 0.305 \\
\hline Item 16 & 0.757 & & & & & 0.326 \\
\hline Item 15 & 0.733 & & & & & 0.45 \\
\hline Item 14 & 0.71 & & & & & 0.325 \\
\hline Item 10 & 0.419 & 0.720 & & & & 0.241 \\
\hline Item 19 & & 0.701 & & & & 0.413 \\
\hline Item 3 & & 0.685 & & & & 0.293 \\
\hline Item 21 & & 0.674 & & & & 0.436 \\
\hline Item 2 & & 0.607 & & & & 0.387 \\
\hline Item 20 & & -0.516 & & & & 0.542 \\
\hline Item 5 & & -0.435 & & & & 0.703 \\
\hline Item 9 & & 0.428 & & & 0.417 & 0.41 \\
\hline Item 11 & & & -0.699 & & & 0.47 \\
\hline Item 7 & & & 0.692 & & & 0.398 \\
\hline Item 1 & & & 0.559 & & & 0.492 \\
\hline Item 8 & & & 0.424 & & & 0.467 \\
\hline Item 4 & & & & 0.803 & & 0.289 \\
\hline Item 12 & 0.495 & & & 0.606 & & 0.371 \\
\hline Item 6 & & 0.413 & & 0.434 & & 0.345 \\
\hline Item 17 & & & & & 0.689 & 0.494 \\
\hline Item 22 & & & & & -0.658 & 0.381 \\
\hline $\begin{array}{c}\text { Variance } \\
\text { explained }\end{array}$ & $18.84 \%$ & $16.86 \%$ & $9.25 \%$ & $9.04 \%$ & $6.32 \%$ & $60.3 \%$ \\
\hline
\end{tabular}

Note: varimax rotation has been applied: values below 0.400 have been assumed for easy reading.

The overall scale had a Cronbach's alpha of 0.870 , together with a McDonald's $\omega$ of 0.876 . It should be noted that items 5, 11 and 20 correlated negatively with the total scale, so it is advisable to reverse the value of their scores. Meanwhile, Cronbach's internal consistency score and the McDonald value improve if items 5 (alpha $=0.885 ; \mathrm{w}=0.890), 11$ $($ alpha $=0.880 ; \mathrm{w}=0.886), 17($ alpha $=0.873 ; \mathrm{w}=0.880)$, and $20($ alpha $=0.880 ; \mathrm{w}=0.888)$ are removed.

Next, a CFA was carried out on the verification subsample based on the four-component structure from the PCA. Table 3 shows the estimated factor loadings. The following items are not significant with a confidence level of $95.00 \%: 15,2,5,20,21,7,11,4,12$, 22, and 9.

Likewise, the three-dimensional CFA model based on the original theoretical structure was also developed. In this case, the following items were not significant in the model: 4 $(p=0.254), 11(p=0.322), 17(p=0.157), 20(0.150)$, and $22(p=0.386)$. The factor loadings of the model are presented in Table 4.

In Table 5, the adjustment measures of both models are compared on the basis of the goodness-of-fit indices. It can be observed that the values of the ratio between chi-square and degrees of freedom indicate a high fit for both models. The CFI and Tucker-Lewis Index (TLI) indicate a low adjustment for both, although somewhat better in the threedimensional model, as it is the one that is closest to 0.900. In the same regard, the SRMR can be interpreted with the mean of the three-dimensional model as an acceptable adjustment, as opposed to a low adjustment in the five-dimensional model. However, the Akaike Information Criterion (AIC) and Bayesian Information Criterion (BIC) values suggest the five-dimensional model is better. In either case, by carrying out an overall interpretation of all the measurement indices and taking into account prior theoretical support, the goodness-of-adjustment of the three-dimensional model cannot be ruled out. 
Table 3. CFA Five-dimensional model: item factor loadings.

\begin{tabular}{|c|c|c|c|c|c|c|c|c|}
\hline \multirow[b]{2}{*}{ Factor } & \multirow[b]{2}{*}{ Indicator } & \multirow[b]{2}{*}{ Estimate } & \multirow[b]{2}{*}{ SE } & \multicolumn{2}{|c|}{$\begin{array}{l}\text { 95\% Confidence } \\
\text { Interval }\end{array}$} & \multirow[b]{2}{*}{$\mathbf{Z}$} & \multirow[b]{2}{*}{$p$} & \multirow[b]{2}{*}{$\begin{array}{l}\text { Stand. } \\
\text { Estimate }\end{array}$} \\
\hline & & & & Lower & Upper & & & \\
\hline \multirow[t]{5}{*}{ Factor 1} & Item 13 & 0.771 & 0.145 & 0.487 & 1.054 & 5.331 & $<0.001$ & 0.725 \\
\hline & Item 14 & 0.630 & 0.116 & 0.401 & 0.858 & 5.411 & $<0.001$ & 0.726 \\
\hline & Item 15 & 0.603 & 0.200 & 0.211 & 0.996 & 3.018 & 0.003 & 0.452 \\
\hline & Item 16 & 0.588 & 0.133 & 0.329 & 0.848 & 4.443 & $<0.001$ & 0.633 \\
\hline & Item 18 & 0.661 & 0.109 & 0.447 & 0.876 & 6.046 & $<0.001$ & 0.792 \\
\hline \multirow[t]{7}{*}{ Factor 2} & Item 2 & 0.249 & 0.124 & 0.006 & 0.492 & 2.008 & 0.045 & 0.316 \\
\hline & Item 3 & 0.721 & 0.123 & 0.481 & 0.962 & 5.878 & $<0.001$ & 0.772 \\
\hline & Item 5 & -0.223 & 0.120 & -0.457 & 0.011 & -1.862 & 0.063 & -0.282 \\
\hline & Item 10 & 0.873 & 0.122 & 0.634 & 1.112 & 7.155 & $<0.001$ & 0.896 \\
\hline & Item 19 & 0.542 & 0.170 & 0.210 & 0.875 & 3.200 & 0.001 & 0.485 \\
\hline & Item 20 & -0.052 & 0.127 & -0.302 & 0.196 & -0.414 & 0.679 & -0.065 \\
\hline & Item 21 & 0.280 & 0.228 & -0.166 & 0.727 & 1.231 & 0.218 & 0.223 \\
\hline \multirow[t]{4}{*}{ Factor 3} & Item 1 & 0.933 & 0.142 & 0.655 & 1.211 & 6.576 & $<0.001$ & 0.826 \\
\hline & Item 7 & 0.252 & 0.177 & -0.093 & 0.599 & 1.429 & 0.153 & 0.219 \\
\hline & Item 8 & 0.797 & 0.133 & 0.535 & 1.058 & 5.980 & $<0.001$ & 0.762 \\
\hline & Item 11 & 0.099 & 0.176 & -0.244 & 0.443 & 0.565 & 0.572 & 0.089 \\
\hline \multirow[t]{3}{*}{ Factor 4} & Item 4 & 0.453 & 0.232 & -0.001 & 0.907 & 1.953 & 0.051 & 0.308 \\
\hline & Item 6 & 0.571 & 0.150 & 0.276 & 0.865 & 3.797 & $<0.001$ & 0.565 \\
\hline & Item 12 & 0.614 & 0.196 & 0.230 & 0.997 & 3.139 & 0.002 & 0.477 \\
\hline \multirow[t]{3}{*}{ Factor 5} & Item 17 & 0.063 & 0.340 & -0.602 & 0.730 & 0.188 & 0.851 & 0.081 \\
\hline & Item 22 & 0.117 & 0.617 & -1.092 & 1.326 & 0.190 & 0.849 & 0.089 \\
\hline & Item 9 & -0.114 & 0.605 & -1.300 & 1.072 & -0.189 & 0.850 & -0.113 \\
\hline
\end{tabular}

Table 4. FAC Three-dimensional model: item component loadings.

\begin{tabular}{|c|c|c|c|c|c|c|c|c|}
\hline \multirow[b]{2}{*}{ Factor } & \multirow[b]{2}{*}{ Indicator } & \multirow[b]{2}{*}{ Estimate } & \multirow[b]{2}{*}{ SE } & \multicolumn{2}{|c|}{$\begin{array}{l}\text { 95\% Confidence } \\
\text { Interval }\end{array}$} & \multirow[b]{2}{*}{$\mathbf{Z}$} & \multirow[b]{2}{*}{$p$} & \multirow[b]{2}{*}{$\begin{array}{l}\text { Stand. } \\
\text { Estimate }\end{array}$} \\
\hline & & & & Lower & Upper & & & \\
\hline \multirow[t]{8}{*}{ Theory } & Item 1 & 0.904 & 0.105 & 0.697 & 1.111 & 8.561 & $<0.001$ & 0.751 \\
\hline & Item 2 & 0.567 & 0.093 & 0.383 & 0.750 & 6.050 & $<0.001$ & 0.598 \\
\hline & Item 3 & 0.711 & 0.098 & 0.517 & 0.905 & 7.199 & $<0.001$ & 0.670 \\
\hline & Item 4 & 0.157 & 0.137 & -0.112 & 0.426 & 1.140 & .254 & 0.121 \\
\hline & Item 5 & -0.424 & 0.086 & -0.593 & -0.254 & -4.901 & $<0.001$ & -0.487 \\
\hline & Item 6 & 0.754 & 0.105 & 0.546 & 0.961 & 7.123 & $<0.001$ & 0.662 \\
\hline & Item 7 & 0.598 & 0.122 & 0.356 & 0.839 & 4.865 & $<0.001$ & 0.484 \\
\hline & Item 8 & 0.895 & 0.098 & 0.703 & 1.087 & 9.132 & $<0.001$ & 0.794 \\
\hline \multirow[t]{10}{*}{ Practice } & Item 9 & 0.776 & 0.109 & 0.561 & 0.991 & 7.075 & $<0.001$ & 0.653 \\
\hline & Item 10 & 0.784 & 0.100 & 0.586 & 0.982 & 7.783 & $<0.001$ & 0.701 \\
\hline & Item 11 & -0.111 & 0.111 & -0.329 & 0.108 & -0.991 & 0.322 & -0.103 \\
\hline & Item 12 & 0.533 & 0.126 & 0.286 & 0.780 & 4.228 & $<0.001$ & 0.428 \\
\hline & Item 13 & 0.788 & 0.102 & 0.587 & 0.988 & 7.701 & $<0.001$ & 0.693 \\
\hline & Item 14 & 0.823 & 0.092 & 0.642 & 1.003 & 8.927 & $<0.001$ & 0.768 \\
\hline & Item 15 & 0.858 & 0.134 & 0.594 & 1.121 & 6.393 & $<0.001$ & 0.613 \\
\hline & Item 16 & 0.815 & 0.099 & 0.620 & 1.011 & 8.182 & $<0.001$ & 0.737 \\
\hline & Item 17 & 0.154 & 0.108 & -0.059 & 0.367 & 1.416 & 0.157 & 0.152 \\
\hline & Item 18 & 0.736 & 0.078 & 0.582 & 0.889 & 9.407 & $<0.001$ & 0.801 \\
\hline \multirow[t]{4}{*}{ Evaluation } & Item 19 & -0.872 & 0.129 & -1.125 & -0.618 & -6.739 & $<0.001$ & -0.748 \\
\hline & Item 20 & 0.150 & 0.104 & -0.054 & 0.354 & 1.440 & 0.150 & 0.166 \\
\hline & Item 21 & -0.765 & 0.132 & -1.025 & -0.504 & -5.753 & $<0.001$ & -0.624 \\
\hline & Item 22 & -0.118 & 0.136 & -0.386 & 0.149 & -0.868 & 0.386 & -0.109 \\
\hline
\end{tabular}


Table 5. Model adjustment measures.

\begin{tabular}{|c|c|c|c|c|c|c|c|c|}
\hline Model & Chi-Square & $\begin{array}{c}\text { Reason } \\
\text { Chi-Square/d.f. }\end{array}$ & CFI & TLI & SRMR & RMSEA & AIC & BIC \\
\hline 5 dimensions & 268 (d.f. $=199 ; p<0.001)$ & 1.34 & 0.758 & 0.719 & 0.114 & 0.084 & 2884 & 3026 \\
\hline 3 dimensions & 347 (d.f. $=206 ; p<0.001)$ & 1.68 & 0.813 & 0.790 & 0.0832 & 0.080 & 6345 & 6529 \\
\hline
\end{tabular}

Based on the three-dimensional model, the internal consistency of the scale was calculated from the total data, obtaining a Cronbach's alpha of 0.860 and McDonald's $\omega$ of 0.867 . This McDonald's $\omega$ value can be increased to 0.881 if item 5 is eliminated.

Finally, a descriptive analysis of the participants was carried out according to their scores for each of the three factors in the above model. For this purpose, the average scores in each factor were calculated. With regard to Factor 1 (theory), the mean was 3.050 $(\mathrm{SE}=0.025)$, with a variance of 0.221 points. Regarding the second factor (practice), the mean was 2.890 points $(\mathrm{SE}=0.038)$, with a variance of 0.510 points. Lastly, the mean score in the assessment factor was 2.430 ( $\mathrm{SE}=0.036$ ), with a variance of 0.473 .

Possible differences in each factor were analysed according to sex, age, and university of origin through one-factor ANOVAs. In none of the contrasts was the homoscedasticity assumption violated at a significance level of 0.050 . Statistically significant differences were only found as a function of university in Factor 2 related to practice $[\mathrm{F}(7 ; 74.900)=3.420$; $p=0.003]$ and the third dimension of assessment $[\mathrm{F}(7 ; 77.200)=2.920 ; p=0.009]$. By applying Tukey's test, it was observed that the differences in the second factor were found between the University of Cádiz and the University of the Balearic Islands (Tukey, mean difference 0.892; $p<0.001$ ). With regard to the third factor related to assessment, no statistically significant difference arose in Tukey's parametric test. Nevertheless, the DwassSteel-Critchlow-Fligner comparison test was applied, revealing statistically significant differences between the University of Cádiz and the University of León ( $\mathrm{W}=-4.698$; $p=0.020$ ) at the 0.050 significance level. No other significant differences were found between universities in the pairwise analyses. Table 6 summarises the descriptive statistics of the universities in order to identify these differences.

Table 6. Model adjustment measures.

\begin{tabular}{|c|c|c|c|c|c|}
\hline & University & $\mathbf{n}$ & Mean & $\begin{array}{l}\text { Standard } \\
\text { Deviation }\end{array}$ & $\begin{array}{c}\text { Standard } \\
\text { Error }\end{array}$ \\
\hline \multirow[t]{8}{*}{ Factor 1 (Theory) } & University of Sevilla & 151 & 3.040 & 0.442 & 0.035 \\
\hline & University of Cádiz & 20 & 2.990 & 0.545 & 0.121 \\
\hline & University of Córdoba & 21 & 3.130 & 0.405 & 0.088 \\
\hline & University of Illes Balears & 35 & 2.940 & 0.528 & 0.089 \\
\hline & University of Jaén & 65 & 3.170 & 0.493 & 0.061 \\
\hline & University of León & 15 & 2.880 & 0.462 & 0.119 \\
\hline & University of Osuna & 21 & 2.950 & 0.446 & 0.097 \\
\hline & Other & 19 & 3.090 & 0.463 & 0.106 \\
\hline \multirow[t]{8}{*}{$\begin{array}{c}\text { Factor } 2 \\
\text { (Practice) }\end{array}$} & University of Sevilla & 151 & 2.930 & 0.666 & 0.054 \\
\hline & University of Cádiz & 20 & 3.420 & 0.672 & 0.150 \\
\hline & University of Córdoba & 21 & 2.730 & 0.516 & 0.112 \\
\hline & University of Illes Balears & 35 & 2.530 & 0.803 & 0.135 \\
\hline & University of Jaén & 65 & 2.990 & 0.744 & 0.092 \\
\hline & University of León & 15 & 2.790 & 0.529 & 0.136 \\
\hline & University of Osuna & 21 & 2.820 & 0.456 & 0.099 \\
\hline & Other & 19 & 2.660 & 0.987 & 0.226 \\
\hline
\end{tabular}


Table 6. Cont.

\begin{tabular}{cccccc}
\hline University & n & Mean & $\begin{array}{c}\text { Standard } \\
\text { Deviation }\end{array}$ & $\begin{array}{c}\text { Standard } \\
\text { Error }\end{array}$ \\
\hline $\begin{array}{c}\text { Factor 3 } \\
\text { (Evaluation) }\end{array}$ & University of Sevilla & 151 & 2.370 & 0.777 & 0.063 \\
& University of Cádiz & 20 & 2.750 & 0.466 & 0.104 \\
& University of Córdoba & 21 & 2.620 & 0.636 & 0.138 \\
& University of Illes Balears & 35 & 2.400 & 0.746 & 0.126 \\
& University of Jaén & 65 & 2.530 & 0.605 & 0.075 \\
& University of León & 15 & 2.130 & 0.442 & 0.114 \\
& University of Osuna & 21 & 2.320 & 0.537 & 0.117 \\
& Other & 19 & 2.410 & 0.501 & 0.115 \\
\hline
\end{tabular}

\section{Discussion}

The main objective of the present study was to investigate the degree of satisfaction among students in the Faculties of physiotherapy throughout Spain concerning online teaching during the SE due to the global pandemic caused by COVID-19. This study demonstrates that on the whole, students are unsatisfied with distance learning during the SE, considering it unsuitable for their learning in either the theoretical or practical field of subjects in the degree of physiotherapy, thereby confirming what has been analysed in different studies among students in HS [7,26-28]. The perception of students in relation to teaching received is more satisfactory if this carried out in-person in the classroom, above all in regard to practical content, and at universities where online platforms were already being used [7,9]. Men are the ones who have the worst consideration of the adequacy of online teaching, while the most critical are those who consider that this type of teaching has not helped them combine their personal life with their studies [7], who consider the presence of a teacher in the classroom to be indispensable. The general satisfaction rate in online HS education was significantly higher in students with experience in distance learning in their faculties, adding the active participation of their teachers, the multimedia use and appropriate time of their sessions [29]. In this respect, differences have been evidenced according to the discipline of study, with HS disciplines and those in creative areas such as the arts, music, and design the most affected [30]. It has been objectively demonstrated that carrying out the more practical aspects of a degree is a challenge, and the teaching provided during the lockdown was limited mainly to the theoretical dimension. These findings are also consistent with a series of surveys where students from eminently practical studies considered this situation a disadvantage to being adequately trained [30].

Despite a thorough search, the authors were unable to find studies related to satisfaction with online classes among physiotherapy students during the SE; therefore, we aimed to correlate our findings with those of other university students linked to HS. The International Association of Universities analyzed the exact consequences of what is also known as emergency digitalization [30], revealing results along the same lines as the ones gathered in our study, showing reduced academic perception and performance in universities with online teaching during the lockdown situation [31,32].

There are several explanations for these findings, as they constitute one of the first approaches to the problems of online training in the degree of physiotherapy, and we believe in studies in the field of HS overall. The students in the first years, who are in the initial phase of their educational journey and need more supervision, guidance, and face-to-face interaction with their lecturers and colleagues, consider that classes ought to be conducted in-person, as they are eminently practical. These data are supported by a study carried out in Australia [33] in which undergraduate students prefer in-person classes, in traditional classrooms, and face-to-face interactions to the online method. It is true that the incorporation and good use of new technologies must continue to complement in-person teaching. Assessment of student satisfaction is a high priority for universities and represents an objective critical tool for continuous improvement. Collecting critical 
comments regarding student satisfaction is necessary in order to continue improving without being oblivious to the realities that these HS students experience first-hand.

Students feel well enough prepared, and they have means available to be able to carry out his type of learning through online platforms; however, they do admit a certain difficulty in the use of these technological resources [28]. This happens above all in centres where online platforms were barely being used. This could be explained due to the need to carry out all the tasks and procedures through these platforms, which despite existing before the SE, had barely been used.

Some researchers $[7,27,34]$ think that online teaching has presented barriers that affect the development and implementation of online learning in HS education due to time constraints, insufficient technical skills on the part of lecturers, inadequate infrastructure in the centres, and little institutional support, although it is true that use of technological advances in the field of medicine were already being used (social networks, smart phones) for teaching and learning [29,35]. In disagreement are the results of the study of Puljak et al. [36], where most HS students were satisfied with exclusive e-learning and personal and institutional adaptation. However, they add that most participants prefer the combination of the classic classroom with e-learning [36]. Our study shows that the technical skills of lecturers are sufficient to carry out their jobs, and that the technological means of the centers are functioning and are continuously evolving to meet new teaching challenges. Time is not a constraint but rather an advantage, above all for students who have to take care of people at home.

The new education situation caused by the pandemic pushed for a rapid adaptation of teaching, both in terms of theoretical-practical contents and teaching programs, to this virtual scenario in schools worldwide [27]. In a review by Sahu P. [8] of the impact on education and on the mental health of students and academic staff, they conclude that it is lecturers who must embrace technology and pay special attention to student experiences in order for learning to be rich and effective [8]. Likewise, a lack of effectiveness of online teaching of subjects with a high practical load was also evidenced [8], which led to a greater workload and to an increase in anxiety, stress, and other mental problems in this university population [31,37]. However, the most effective approach to education was found to be through practical rather than theoretical learning. Therefore, education for practice requires more practical content. Student learning is a dynamic process that needs care. Limiting the amount of practice time decreases students' capacity for reflective learning that helps them in the future to cope with the broad reality of professional work [38]. The data from our study show that students report insufficient adaptation by lecturers, possibly due to the unexpected arrival of the pandemic and the need for rapid adaptation to online teaching, data that are consistent with the study by Singh et al., in which they point out that as lecturers were healthcare workers who had to continue their clinical practice, they did not have enough time to prepare online classes [7]. Thus, a large majority of respondents declared they were dissatisfied with the help they received from teaching staff, stating that it had led to a loss of information quality. In our study, students positively rated the implementation and rapid adaptation to online teaching but considered that there was a greater loss of understanding of practical content at the time of the SE. Once again, the perception of not receiving enough help coincided with a lack of understanding of practical content. There was almost total affirmation of a loss of practical exercises during the SE, with very few students being able to do any practice at home and most being worried that the online explanation of techniques and maneuvers was not clear enough to be able to put them into practice correctly with a real patient. These data match those of a systematic review of HS students [39] where the suspension of clinical practice inevitably affected their training.

This study reflects that a high percentage of students recognize a significant loss of adaptation of assessment methods during the confinement, giving a negative score to the online teaching provided, above all in the explanations of eminently practical techniques. Likewise, a greater workload is revealed among students in the first three years, making 
study scheduling difficult, and with demotivation especially appearing among the youngest students. These results are in line with studies where problems of demotivation and anxiety were objectively determined in students facing this new situation [31,40]. This could be due to the fact that students in the first years require the completion of more years to feel better trained, and are still in the initial phase of their educational journey, needing more supervision, guidance, and face-to-face interaction with their lecturers and colleagues. As these are eminently practical studies, not being able to practice manoeuvres or procedures in an in-person setting that simulates clinical reality leads to experiencing fear of not acquiring sufficient skills to enable them to deal with real clinical situations successfully, both in the context of curricular clinical practice and subsequently in professional practice. This further highlights the fact that they come from an educational model focused on the face-to-face supervision of the lecturer or tutor.

Meanwhile, there is interference between class and working hours which can undermine the nature of virtual education and input conditions [33]. Of the $21 \%$ of subjects who have a dependent in their care, $54.1 \%$ declared a greater tendency to not considering in-person teaching necessary for the acquisition of content, with on-line teaching helping them combine their personal and work life and hours of study, a detail that contradicts the results of several studies $[33,41]$ which found that working and studying at the same time could overwhelm the acceptance of technology and create problems for electronic learning programmes.

A significant barrier was access to technology and slow Internet speed [7,35]; these results are consistent with our own; although only $1.4 \%$ of students did not have an Internet connection, and $2 \%$ did not have an adequate computer and did not consider this situation a barrier to being able to follow the course normally, it was the subjects who did not have internet who were significantly more critical and responded most negatively compared to those who did have internet. This fact evidences an inequality of opportunity for students. An interesting solution would be to provide and distribute technical material (tablets) and make an internet connection available to the students affected, so as to minimise these differences [42].

The evaluation of student satisfaction is a high priority for the Universities and represents an objective critical tool for continuous improvement. Collecting critical comments and student satisfaction is necessary to continue improving without being oblivious to the reality that these HS students experience in the first person.

Students do not see e-learning as a replacement for traditional training directed by an instructor, but rather as a complement thereto, forming part of a blended learning strategy $[13,36]$. This sudden shift in the type of teaching raises many questions both for the future of students and teaching staff. We consider that this boom in teaching technology is going to play a determining role in university structure [29]. Proper use must be made of it, and it must be considered that in physiotherapy, a practical degree, teaching must continue to be in-person as far as possible.

More studies must be carried out in HS students concerning this implementation of online teaching, about which we do not know whether or not it is here to stay. The pandemic has changed the educational landscape forever. COVID-19 is an ongoing crisis; it is a lesson in real time [43].

It can be said that students are unsatisfied with distance learning during the SE, considering it unsuitable for their training in either the theoretical or practical field of subjects in physiotherapy studies in Spain. These results allow health teachers to know the degree of satisfaction of their students. With the DISFISCOVID questionnaire, we have a reliable new measurement tool to measure the degree of satisfaction perceived by students during their university studies of physiotherapy. This knowledge could allow the implementation of future practices aimed at improving indicators related to satisfaction. These indicators would allow an increase in the quality of the university studies in physiotherapy. Moreover, the quality of Degrees could be compared between universities. 


\section{Strengths and Limitations}

One strong point of this study is that it is the only one of its kind to date conducted among HS students at the national level to reflect the feelings of numerous Spanish students during this extraordinary situation. Another strength is that our results highlight the close relationship between students and lecturers in these undergraduate studies, the need for in-person teaching in the theoretical part and above all in the practical part, and the ease of adaptation of both lecturers and students in this unexpected situation. In addition, a questionnaire was created and validated that enables online teaching in physiotherapy to be assessed. Knowledge of the normative scores of the DISFISCOVID questionnaire as well as the identification of different predictors in online teaching, including sociodemographic, theoretical, practical, and assessment characteristics of Spanish physiotherapy students, will enable comprehensive assessment thereof, and the use of specific strategies and intervention/action plans for the purpose of helping on-going improvement in the quality of online teaching in physiotherapy studies; should it become necessary to restart online learning again, we consider this to be another important strength.

By way of weaknesses, the choice of time for the dissemination of the questionnaire when this study was conducted (June 2020) might have had a bearing on the negativity of the response of students to online teaching, accustomed as they were to in-person teaching and to closer contact with teaching staff and peers; the environmental factors, fear, and health uncertainty they were experiencing may have influenced some respondents.

Another limitation could be that due to being an online survey, and because of the exceptional situation of lockdown and isolation experienced by society, students might have perceived this change in distance learning differently.

In view of these limitations, we consider our article adds to the literature on this issue.

Author Contributions: Conceptualization: I.E.-P.; methodology: all authors; software: A.M.-T.; validation: I.E.-P., M.A.-C.; formal analysis: M.A.-C. and A.M.-T.; investigation: I.E.-P., R.S.-S., M.G.-M. and J.A.M.; resources: I.E.-P., M.A.-C. and A.M.-T.; data curation: M.A.-C. and A.M.-T.; writing-original draft: I.E.-P.; writing-review \& editing: all authors; visualization: I.E.-P., R.S.-S., M.G.-M. and J.A.M.; supervision: I.E.-P. and M.A.-C.; project administration: I.E.-P. All authors have read and agreed to the published version of the manuscript.

Funding: This research received no external funding.

Institutional Review Board Statement: The study protocol was supervised by the institutional ethics committee CEI University Hospital Virgen Macarena and Virgen del Rocio, with ethics approval number 1892-N-20. The research was conducted according to the Declaration of Helsinki.

Informed Consent Statement: All enrolled participants were informed of the purpose of the study and their participation was voluntary. No incentives were provided for participation.

Data Availability Statement: The data presented in this study are available on request from the corresponding author.

Acknowledgments: The authors would like to thank all physiotherapy students for their time and effort in completing this questionnaire.

Conflicts of Interest: The authors declare no conflict of interest.

\section{References}

1. World Health Organization. Coronavirus Disease (COVID-19) Advice for the Public; World Health Organization: Geneva, Switzerland, 2020.

2. Rose, S. Medical Student Education in the Time of COVID-19. JAMA 2020, 323, 2131-2132. [CrossRef] [PubMed]

3. Longhini, J.; De Colle, B.; Rossettini, G.; Palese, A. What knowledge is available on massive open online courses in nursing and academic healthcare sciences education? A rapid review. Nurse Educ. Today 2021, 99, 104812. [CrossRef] [PubMed]

4. Haslam, M.B. What might COVID-19 have taught us about the delivery of Nurse Education, in a post-COVID-19 world? Nurse Educ. Today 2021, 97, 104707. [CrossRef] [PubMed] 
5. Ministerio de la Presidencia. Relaciones con las Cortes y Memoria Democrática. Agencia Estatal Boletín Oficial del Estado. Real Decreto 463/2020, de 14 de Marzo, por el que se Declara el Estado de Alarma para la Gestión de la Situación de Crisis Sanitaria Ocasionada por el COVID-19. Available online: https:/ /www.boe.es/eli/es/rd/2020/03/14/463/com (accessed on 20 May 2019).

6. $\quad$ Longhurst, G.J.; Stone, D.M.; Dulohery, K.; Scully, D.; Campbell, T.; Smith, C.F. Strength, Weakness, Opportunity, Threat (SWOT) Analysis of the Adaptations to Anatomical Education in the United Kingdom and Republic of Ireland in Response to the Covid-19 Pandemic. Anat. Sci. Educ. 2020, 13, 301-311. [CrossRef] [PubMed]

7. Singh, H.K.; Joshi, A.; Malepati, R.N.; Najeeb, S.; Balakrishna, P.; Pannerselvam, N.K.; Singh, Y.K.; Ganne, P. A survey of E-learning methods in nursing and medical education during COVID-19 pandemic in India. Nurse Educ. Today 2021, $99,104796$. [CrossRef]

8. Sahu, P. Closure of Universities Due to Coronavirus Disease 2019 (COVID-19): Impact on Education and Mental Health of Students and Academic Staff. Cureus 2020, 12, e7541. [CrossRef]

9. Gaur, R.; Mudgal, S.K.; Dharni, I.T.; Sharma, R.; Suyal, N. Barriers encountered during online classes among undergraduate nursing students during COVID-19 pandemic in India. Int. J. Res. Med Sci. 2020, 8, 3687-3693. [CrossRef]

10. Cervantes, R.F.; Camba, S.S. La educación de fisioterapia en tiempos de la COVID-19. Fisioterapia 2020, 42, 283-285. [CrossRef]

11. Masic, I. E-Learning as New Method of Medical Education. Acta Inform. Medica 2008, 16, 102-117. [CrossRef]

12. A Cook, D.; Triola, M. What is the role of e-learning? Looking past the hype. Med Educ. 2014, 48, 930-937. [CrossRef]

13. Ruiz, J.G.; Mintzer, M.J.; Leipzig, R.M. The Impact of E-Learning in Medical Education. Acad. Med. 2006, 81, 207-212. [CrossRef]

14. García-Peñalvo, F.J.; Corell, A.; Abella-García, V.; Grande, M. La evaluación online en la educación superior en tiempos de la COVID-19. Educ. Knowl. Soc. (EKS) 2020, 21, 26. [CrossRef]

15. Hall, A.K.; Nousiainen, M.T.; Campisi, P.; Dagnone, J.D.; Frank, J.R.; Kroeker, K.I.; Brzezina, S.; Purdy, E.; Oswald, A. Training disrupted: Practical tips for supporting competency-based medical education during the COVID-19 pandemic. Med Teach. 2020, 42, 756-761. [CrossRef]

16. Ministerio de Educación y Formación Profesional. Ministerio de Universidades. EDUCAbase. Available online: http: / / estadisticas.mecd.gob.es/EducaJaxiPx/Datos.htm?path=/Universitaria/EUCT/Serie/Titulaciones / / 10/\&file=Titulaciones_ Inter_Nivel_Rama_Tot.px\&type=pcaxis (accessed on 20 May 2019).

17. Ferrel, M.N.; Ryan, J.J. The Impact of COVID-19 on Medical Education. Cureus 2020, 12, e7492. [CrossRef]

18. Carretero-Dios, H.; Pérez, C. Standards for the development and review of instrumental studies: Considerations about test selection in psychological research. Int. J. Clin. Health Psychol. 2007, 7, 863-882.

19. Stevens, J. Applied Multivariate Statistics for the Social Sciences, 3rd ed.; Lawrence Erlbaum Associates: Mahwah, NJ, USA, 1996.

20. Hair, J.F.; Anderson, R.E.; Tatham, R.L.; Black, W.C. Multivariate Data Analysis, 5th ed.; Prentice Hall: Upper Saddle River, NJ, USA, 1998.

21. Kline, T.J.B. Psychological Testing: A Practical Approach to Design and Evaluation, 1st ed.; SAGE Publications: Thousand Oaks, CA, USA, 2005.

22. Brown, T.A. Confirmatory Factor Analysis for applied Research, 1st ed.; Guilford: New York, NY, USA, 2006.

23. Hu, L.T.; Bentler, P.M. Cutoff criteria for fit indexes in covariance structure analysis: Conventional criteria versus new alternatives. Struct. Equ. Model. Multidiscip. J. 1999, 6, 1-55. [CrossRef]

24. Browne, M.W.; Cudeck, R. Alternative ways of assessing model fit. In Testing Structural Equation Models, 1st ed.; Bollen, K.A., Long, J.S., Eds.; Sage: Newbury Park, CA, USA, 1993.

25. R Core Team. R: A Language and Environment for Statistical Computing; R Foundation for Statistical Computing: Vienna, Austria, 2015; Available online: https:/ / www.R-project.org/ (accessed on 7 June 2013).

26. Odriozola-González, P.; Planchuelo-Gómez, A.; Irurtia, M.J.; de Luis-García, R. Psychological effects of the COVID-19 outbreak and lockdown among students and workers of a Spanish university. Psychiatry Res. 2020, 290, 113108. [CrossRef]

27. Latif, M.; Hussain, I.; Saeed, R.; Qureshi, M.; Maqsood, U. Use of Smart Phones and Social Media in Medical Education: Trends, Advantages, Challenges and Barriers. Acta Inform. Medica 2019, 27, 133-138. [CrossRef] [PubMed]

28. Langfield, T.; Colthorpe, K.; Ainscough, L. Online instructional anatomy videos: Student usage, self-efficacy, and performance in upper limb regional anatomy assessment. Anat. Sci. Educ. 2018, 11, 461-470. [CrossRef]

29. Al-Balas, M.; Al-Balas, H.I.; Jaber, H.M.; Obeidat, K.; Al-Balas, H.; Aborajooh, E.A.; Al-Taher, R.; Al-Balas, B. Distance learning in clinical medical education amid COVID-19 pandemic in Jordan: Current situation, challenges, and perspectives. BMC Med Educ. 2020, 20, 1-7. [CrossRef]

30. Kemp, N.; Grieve, R. Face-to-face or face-to-screen? Undergraduates' opinions and test performance in classroom vs. online learning. Front. Psychol. 2014, 5, 1278. [CrossRef] [PubMed]

31. Marinoni, G.; van't Land, H.; Jensen, T. The Impact of COVID-19 on Global Higher Education around the World; International Association of Universities: Paris, France, 2020; ISBN 978-92-9002-212-1.

32. Sintema, E.J. Effect of COVID-19 on the Performance of Grade 12 Students: Implications for STEM Education. Eurasia J. Math. Sci. Technol. Educ. 2020, 16, em1851. [CrossRef]

33. Shahmoradi, L.; Changizi, V.; Mehraeen, E.; Bashiri, A.; Jannat, B.; Hosseini, M. The challenges of E-learning system: Higher educational institutions perspective. J. Educ. Heal. Promot. 2018, 7, 116-124. [CrossRef] 
34. Long, K.C. E-Learning, Information Technology, and Student Success in Higher Education. In Oxford Research Encyclopedia of Business and Management; Oxford University Press; Available online: https:/ / oxfordre.com/business/view/10.1093/acrefore/97 80190224851.001.0001/ acrefore-9780190224851-e-78 (accessed on 1 June 2019).

35. O'Doherty, D.; Dromey, M.; Lougheed, J.; Hannigan, A.; Last, J.; McGrath, D. Barriers and solutions to online learning in medical education-An integrative review. BMC Med Educ. 2018, 18, 1-11. [CrossRef]

36. Puljak, L.; Čivljak, M.; Haramina, A.; Mališa, S.; Čavić, D.; Klinec, D.; Aranza, D.; Mesarić, J.; Skitarelić, N.; Zoranić, S.; et al. Attitudes and concerns of undergraduate university health sciences students in Croatia regarding complete switch to e-learning during COVID-19 pandemic: A survey. BMC Med. Educ. 2020, 20, 1-11. [CrossRef] [PubMed]

37. Liang, L.; Ren, H.; Cao, R.; Hu, Y.; Qin, Z.; Li, C.; Mei, S. The Effect of COVID-19 on Youth Mental Health. Psychiatr. Q. 2020, 91, 841-852. [CrossRef]

38. Morley, D. Applying Wenger's communities of practice theory to placement learning. Nurse Educ. Today 2016, 39, 161-162. [CrossRef]

39. Dedeilia, A.; Sotiropoulos, M.; Hanrahan, J.G.; Janga, D.; Dedeilias, P.; Sideris, M. Medical and Surgical Education Challenges and Innovations in the COVID-19 Era: A Systematic Review. In Vivo 2020, 34 (Suppl. 3), 1603-1611. [CrossRef]

40. YoungMinds. Coronavirus: Impact on Young People with Mental Health Needs. 2020. Available online: https:/ youngminds. org.uk/media/3708/coronavirus-report_march2020.pdf (accessed on 10 October 2020).

41. Shawaqfeh, M.S.; Al Bekairy, A.M.; Al-Azayzih, A.; A Alkatheri, A.; Qandil, A.M.; A Obaidat, A.; Al Harbi, S.; Muflih, S.M. Pharmacy Students Perceptions of Their Distance Online Learning Experience During the COVID-19 Pandemic: A Cross-Sectional Survey Study. J. Med. Educ. Curric. Dev. 2020, 7, 2382120520963039. [CrossRef]

42. Cao, W.; Fang, Z.; Hou, G.; Han, M.; Xu, X.; Dong, J.; Zheng, J. The psychological impact of the COVID-19 epidemic on col-lege students in China. Psychiatry Res. 2020, 287, 112934. [CrossRef] [PubMed]

43. Dewart, G.; Corcoran, L.; Thirsk, L.; Petrovic, K. Nursing education in a pandemic: Academic challenges in response to COVID-19. Nurse Educ. Today 2020, 92, 104471. [CrossRef] [PubMed] 